\title{
IMPLEMENTATION OF THE EU OPERATIONAL PROGRAM EMPLOYMENT AND SOCIAL INCLUSION IN THE SLOVAK REPUBLIC IN THE CONTEXT OF SELECTED SOCIAL INDICATORS
}

\author{
Vladimír KOVÁČIK, PhD \\ Faculty of Social Sciences, University of Ss. Cyril and Methodius in Trnava, Slovakia \\ vladimir.kovacik@ucm.sk \\ Michal IMROVIČ, PhD \\ Faculty of Social Sciences, University of Ss. Cyril and Methodius in Trnava, Slovakia \\ michal.imrovic@ucm.sk
}

\begin{abstract}
The Operational program Employment and social inclusion was implemented in the programming period 2007-2013 by the Ministry of Labor, Social Affairs and Family of the Slovak Republic. The aim of the operational program was to increase employment, social inclusion and capacity building. Due to the low flexibility and efficiency of the staff in various areas of public administration, as well as the need to improve policy-making, the operational program supported activities aimed at improving human capital and activities oriented towards quality policy making. This paper analyses selected key social indicators such as employment rate, unemployment rate and people at risk of poverty or social exclusion rate in the context of the implementation. Active labor market measures are among the most effective instruments the state has to support employment and deal with the threat of poverty and social exclusion. The implementation of the operational program can be considered successful on the basis of results of realized projects and objectives achieved. The operational program helped mitigate the impact of the crisis on employment and started communitywide social and community work. As a result of the analysis, the implementation of the operational program significantly helped to increase employment, reduce unemployment rate and people at risk of poverty or social exclusion rate in Slovakia in the period of 2007-2017.
\end{abstract}

Keywords: Regional policy, EU Structural Funds, European Social Fund, Active labor market policy, Operational Program, Unemployment.

\section{Introduction}

The support of employment, job creation and competitiveness is one of the main challenges of the European Union in order to ensure the progress of smart, sustainable and inclusive growth of the Member 
States (Brzeszczak and Imiołczyk, 2016; Balcerzak, 2016). The financial and economic crisis revealed weaknesses in Member States labour markets and influenced key social and socioeconomic indicators such as employment or people at risk of poverty significantly. Social indicators are defined as statistical measures that describe social trends and conditions impacting on human well-being (OECD, 1976).

Member States and the Union are to work towards developing a coordinated strategy for employment and particularly for promoting a skilled, trained and adaptable workforce and labour markets responsive to economic change with a view to achieving the objectives of full employment and social progress set out in Article 3 of the Treaty on European Union (European Union, 2015; Nagy, 2016).

To prevent another economic crisis to significantly influence labour markets, the EU Member States have taken the employment policy as one of the highest priorities with the common concern approach that coordinates this matter with the EU Council. To be able to exercise the measures of the effective employment policy of the EU, it is necessary to adopt the relevant legislation and define the financial resources to cover the investments. In addition to state budget funding, the EU funding is the largest financial source to cover the employment policy expenditures in EU Member States.

In Slovakia, the programming period 2007-2013 was the second programming period in which the country was eligible to draw EU funds after becoming the full member of the EU. The area of employment policy in the programming period 2007-2013 was supported by the Operational Program Employment and Social Inclusion.

The Operational Program Employment and Social Inclusion (OP EaSI) is a reference document that provided support for human resources development, employment growth, social inclusion and capacity building in the 2007-2013 programming period. The aim of the operational program is to increase employment, social inclusion and capacity building. Due to the low flexibility and efficiency of the staff in various areas of public administration, as well as the need to improve policy-making, the Operational Program supported activities aimed at improving human capital and activities oriented towards quality policy making.

With its priority axes, the OP EaSI was linked to the activities of the Regional Operational Program, OP Education, OP Research and Development and OP Health Service as described in the description of the individual priority axes. The OP EaSI has implemented activities through which the employment policy objectives of the National Reform Program have been fulfilled. Through its priority axes, it has concentrated on contributing to achieving a high level of employment, reducing long-term unemployment, dealing with demographic changes and social inclusion. Contributions in these areas were directed to strengthen the processes aimed at ensuring the competitiveness of the Slovak Republic (SR) in the European and global 
framework. The OP EaSI was approved by the EC on 26 October 2007. The Managing Authority of the OP EaSI is the Ministry of Labor, Social Affairs and Family of SR.

\section{Materials and Methods}

The objective of this paper is to analyse the impact of implementation of OP EaSI on the selected social indicators in Slovakia during 10 years period 2007-2017. In this paper, we were working with secondary data. The secondary data regarding the implementation of the OP EaSI, including achieved drawdown and the indicators used for the analysis in this paper were obtained from Annual Reports of the Implementation of the OP EaSI for 2007-2015, websites of the Ministry of Labor, Social Affairs, and Family of the SR, Implementation agency of Slovak Ministry of Employment, Social Affairs and Family and Ministry of finance of the SR. The secondary data regarding the employment and unemployment rate, people at risk of poverty or social exclusion rate in Slovakia in 2007-2017 were obtained from Eurostat and Statista websites. The data we used in this paper were quantitative.

The main aim of the contribution is to analyse the relation between the results of the implementation of the OP EaSI through the results achieved by drawing the individual priority axes as well as selected measurable indicators (such as the number of jobs created, the number of persons in the target groups involved in the projects) and selected socioeconomic indicators (development of employment and unemployment, poverty and social inclusion).

For research, we were analysing the impact of implementation on the trend in employment rates, poverty and social inclusion. We focused on the relation of the unemployment and employment development in individual years to the number of jobs created and the number of persons involved in the project. We were also interested in the rate of poverty and social inclusion in individual years in relation to the pre-invested funds of the operational program during the reference period. To achieve the objective, the methods of analysis, synthesis, deduction and induction have been used. Another key method that has been used was the descriptive statistics, and for better visualization, we used a graphical representation of the identified values.

\section{Results and Discussion}

\section{Employment and Social Inclusion}

Employment and productive work are key components of social and economic development as well as decisive determinants of human identity. Economic growth, sustainable development and the expansion of 
productive employment are closely linked. Effective employment is also an effective method of dealing with poverty and promoting social integration of citizens.

„The biggest challenges of the economic policy in Slovakia are solutions that align the consolidation objectives with the goals of growth, employment and quality of life. That is why the costs encouraging the economic growth and employment are preferred. This will create the preconditions for faster and sustainable economic growth and achieve a higher level of employment and improve the quality of life"(Ministry of Labor, Social Affairs and Family of the SR, 2014). A necessary condition for further development of the Slovak economy and raising the standard of living of the population is the solution of employment, which will lead to the creation of sustainable jobs.

In every society, the state has an irreplaceable role in the implementation of employment policy. The role of employment policy at the national level is, in coordination with other policies, to create the conditions for entering the labor market for all who can work (Kubík, Zůvala, 2018), want to work and seek work, and for sustainable employment. Increasing the participation of the population in the productive age on employment, or increasing employment rates and particularly for disadvantaged people, and their remaining in the labor market is also one of the main policy instruments against the spread of poverty and social exclusion.

In the demographic aging of the population, job cuts and rising unemployment (LewandowskaGwarda, 2018), a higher degree of economic policy coordination, employment policy for both the EU and national policy is needed. Such an approach should contribute to the promotion of economic growth, job creation in the future and overall improvement in the quality of life. At the same time, it supports and encourages efforts by states to ensure the financial and social sustainability of applied social protection systems.

"The labor market has long been one of the main challenges of the Slovak economy. Compared to other EU countries, Slovakia has relatively low employment rates, especially among young people, but also elderly and women, and high unemployment, which is dominated by long-term unemployment. Long-term unemployed are the largest group of unemployed in Slovakia. The long-term unemployment rate in Slovakia is among the highest in the EU 28" (National reform program, 2014). It is mainly due to the high unemployment rate of the young people and the long-term unemployed low-skilled labor force (Mura et. Al., 2019). Unemployment in Slovakia as well as in the European Union has come to the forefront of the perception of the society, politicians and the professional public. 
The negative effects of unemployment are visible across the whole society, not just the unemployed. "As a result of unemployment, incomplete exploitation of the working population is achieved and the economy cannot work at the level of its potential, it even loses its potential" (Páleník et al., 2014; Chocholatá, Furková 2018; Mészáros, 2018). One of the reasons for the persistence of high unemployment in Slovakia is the absence of an approach that would address in a comprehensive way the problems of employment and unemployment in their mutual relations and taking into account the factors influencing the solution of these problems.

Unemployment is a situation in which part of the working-age population does not participate in the workforce, and this phenomenon contributes significantly to the unfavourable development of public finances (Kargol-wasiluk,, Wildowicz-giegiel, 2018; Androniceanu et al., 2019), but also reflects the potential underutilisation of production capacity in the economy (Workie Tiruneh - Štefánik et al., 2014). However, the high unemployment rate is not only associated with a lack of demand for labour, but is also the result of a mismatch between them (Workie Tiruneh et al., 2013).

Searching for solutions, that will lead to the creation of sustainable jobs for further development of the Slovak economy and raising the living standards of the population, is the main challenge. By promoting employment, it is necessary to focus on measures aimed at removing employment barriers and allowing flexible forms of employment as well as reform changes in active labor market policies and changes in the field of labor protection. Recently, there is a growing problem with the lack of skilled labor in some sectors of the economy.

Considering the facts mentioned above, it is very important and necessary to implement effectively active and passive labor market measures in the SR. Under the notion of labor market policy, we include a system of support and assistance that helps citizens adapt to jobs in the labor market. "A traditional rationale for active labor market policy has been to facilitate the matching process in the labor market" (Calmfors, 1994). Labor market policies include different forms, actions, measures or instruments that should be applied to employment services. The role of the active labor market policy (ALMP) is not only to help the individuals but also to motivate them (Mura, Vlacseková, 2018) and bundle them to their own efforts, which would improve their situation. On the other hand, Hotz, Imbens, and Klerman (2006) find that while active labor market programs that promote a quick return to work can look relatively more favorable over shorter time horizons, programs that invest in human capital development look relatively better over longer horizons.

Active labour market measures are among the most effective instruments the state has to support employment and deal with the threat of poverty and social exclusion. An ALMP is a historically younger 
form of labor market policy; it started to develop in Europe after the Second World War and more pronounced in the 1970s, when passive policy measures stopped taking action, unemployment support started demoralizing people's attitudes towards work, and expenditures for spending on them expeditiously increased, therefore the focus of policy has begun to shift to its active measures (Hetteš, 2013). An ALMP aims to help those people, who are at risk of unemployment as well as helping the unemployed to get to work before they become long-term unemployed. Today, academic analysis of ALMPs is associated with economists such as Calmfors (1994), Layard (1991), Manová et al. (2018), Horecký (2018).

Active labor market measures should meet multiple objectives. The first is to help people who are at risk of unemployment. The second objective is to help unemployed people who are at risk of long-term unemployment. Third is to be effective in helping the long-term unemployed. Active measures are implemented, for example, through job mediation, providing professional counselling services, education and training for the labour market. ALMP are used to combat labour shortages and mobilize labour by reducing the overall level of unemployment (Greeve, 2018).

For the market economy, it is typical that the product and service markets operate in parallel and therefore also the labor market where the wage-earning work is being bought and sold. However, the labor market is a very specific market, its specificities result from the fact that work is a function of labor and is closely linked to a person's personality. "Labor force, although it is carried out via the labor market, is not to be considered as a product either in a legal or ethical sense" (Kováčová, 1995).

Social inclusion requires a comprehensive, multidimensional and especially unified approach in different policy areas. Their main objectives are to promote the social inclusion of disadvantaged or excluded people, to promote equal opportunities, to meet the social needs of people through active and preventive social inclusion measures, and overall to boost employment growth, social cohesion and sustainable development. "Fast growth in some large emerging economies has led to a partial convergence in living standards, which exists side by side with abject poverty and a persistence of inequalities. Inequality undermines prospects for inclusive growth, equal access to social protection, and broader sustainable development" (United Nations, 2013).

Social inclusion is a process that ensures that those at risk of poverty and social exclusion are given opportunities and the necessary resources to be able to participate fully in economic, social and cultural life and have the same standard of living and well-being that is considered to be commonplace in the society in which they live. It provides them with greater participation in decision-making, which affects their lives and access to fundamental rights. 
Reducing poverty and social exclusion is one of the main challenges for ensuring social cohesion in Europe. "Being socially excluded means having unequal access to the five basic sources of society (education, employment, housing, social protection, health care), difficult access to the main social institutions responsible for the distribution of life opportunities, and, last but not least, the separation from important areas of life integration in a given community or society "(Gerbery and Džambazovič, 2011). The main causes of social exclusion are poverty, ethnicity, nationality, religion, health, sexual orientation and many other factors. "Socially excluded from society are those who, for reasons beyond their control, cannot participate in the normal activities of their fellow citizens" (Mareš and Sirovátka, 2008).

\section{Operational Program Employment and Social Inclusion}

The global objective of the OP EaSI was defined as "employment growth, decrease in unemployment, social inclusion and capacity building". The ambition of the global objective was to move towards a balance in the labor market, i.e. full employment of the economically active population and the occupancy of the jobs created. From the European social fund (ESF) source, $€$ 941,301,578 was allocated for the implementation of OP EaSI activities for 2007 - 2013 programming period.

The main objectives of the OP EaSI linked to the global objective were to:

1. Increasing employment and adaptability and reducing unemployment;

2. Strengthen the integration of people at risk of social exclusion or social exclusion and promote reconciliation of work and family life;

3. Improving the quality of human resources and management in the field of public policy.

OP EaSI was implemented in the period from 01.01.2007 to 31.12.2015, within the Convergence objective (Western, Eastern and Central Slovakia) where the $98,11 \%$ of the allocation was concentrated, and also under the Regional Competitiveness and Employment objective (the Bratislava Self-Government region) where 1,89\% of the program allocation was concentrated. The Ministry of Labor, Social Affairs and the Family of the SR was, according to Government Resolution of the SR no. 832 dated October 8, 2006 designated as the Managing authority for OP EaSI. Intermediate Bodies under the Managing Authority were, according to Government Resolution no. 1023 dated December 6, 2006 designated: the Social Implementation 
Agency; Social Development Fund; Implementing Agency for the Operational Program Employment and Social Inclusion.

OP EaSI was implemented through five priority axes from the ESF. The ESF contributes to the EU's priorities in terms of strengthening economic and social cohesion by improving the opportunities for employment and employment, promoting a high level of employment and increasing the number and quality of jobs. It does so by supporting Member State policies aimed at achieving full employment and quality and productivity at work, promoting social inclusion, including access for disadvantaged people to employment, and reducing national, regional and local employment disparities.

Table 1: Priority axes of OP EaSI with allocations

\begin{tabular}{|l|l|l|}
\hline Priority axis & Priority axis & Priority axis allocation \\
\hline Priority axis 1 & Supporting employment growth & 654887200 \\
\hline Priority axis 2 & Supporting social inclusion & 174200000 \\
\hline Priority axis 3 & $\begin{array}{l}\text { Supporting employment, social inclusion } \\
\text { and capacity building in BSR }\end{array}$ & 17801578 \\
\hline Priority axis 4 & $\begin{array}{l}\text { Building capacities and improving the } \\
\text { quality of public administration }\end{array}$ & 5742800 \\
\hline Priority axis 5 & Technical Assistance & 36940000 \\
\hline
\end{tabular}

Source: Ministry of Labor, Social Affairs and Family of the SR. (2013). The Operational Program Employment and Social Inclusion

\section{Results of the implementation of the OP EaSI in 2007-2013 period}

Within the OP EaSI, based on information from Annual reports of the implementation of the OP EaSI overall 4,439 grant applications were submitted, but due do the cancellation of some calls only 4,161 grant applications were further processed. Overall, there were 1,906 projects contracted, i.e. $45.81 \%$ of the grant applications were converted into projects (Lietava, Fáziková, 2017). This is caused by the long-term high interest in ESF projects by the project applicants.

The ESF focuses on four key areas: increasing the adaptability of workers and enterprises, enhancing access to employment and participation in the labor market, reinforcing social inclusion 
by combating discrimination and facilitating access to the labor market for disadvantaged people, and promoting partnership for reform in the fields of employment and inclusion. Out of 1,906 OP EaSI contracted projects, only 1,546 of them were properly finished.

Within the OP EaSI, 1,906 projects were contracted in the total sum of 1430007471.96 EUR. After deducting prematurely terminated projects, the final figure is 1,546 projects in the total contract sum of 1286504 896.96 EUR (EUR 1095656969.33 from EU source).

Table 2: Implementation of OP EaSI for the programming period 2007-2013

\begin{tabular}{|c|c|c|c|c|c|}
\hline OP EaSI & $\begin{array}{l}\text { Submitted } \\
\text { grant } \\
\text { applications }\end{array}$ & $\begin{array}{l}\text { Approved } \\
\text { grant } \\
\text { applications }\end{array}$ & $\begin{array}{l}\text { Contracted } \\
\text { projects }\end{array}$ & $\begin{array}{l}\text { Contracted projects } \\
\text { without prematurely } \\
\text { terminated projects }\end{array}$ & $\begin{array}{l}\text { Prematurely } \\
\text { terminated } \\
\text { projects }\end{array}$ \\
\hline Measure 1.1 & 47 & 45 & 44 & 43 & 1 \\
\hline Measure 1.2 & 1,646 & 620 & 612 & 470 & 142 \\
\hline Priority axis 1 & 1,693 & 665 & 656 & 513 & 143 \\
\hline Measure 2.1 & 1,286 & 707 & 707 & 602 & 105 \\
\hline Measure 2.2 & 444 & 168 & 168 & 132 & 36 \\
\hline Measure 2.3 & 145 & 19 & 19 & 17 & 2 \\
\hline Priority axis 2 & 1,875 & 894 & 894 & 751 & 143 \\
\hline Measure 3.1 & 100 & 38 & 38 & 32 & 6 \\
\hline Measure 3.2 & 45 & 24 & 24 & 21 & 3 \\
\hline Measure 3.3 & 36 & 35 & 33 & 20 & 13 \\
\hline Measure 3.4 & 16 & 16 & 16 & 16 & 0 \\
\hline Priority axis 3 & 197 & 113 & 111 & 89 & 22 \\
\hline Measure 4.1 & 627 & 202 & 201 & 152 & 49 \\
\hline Measure 4.2 & 3 & 1 & 1 & 1 & 0 \\
\hline Priority axis 4 & 630 & 203 & 202 & 153 & 49 \\
\hline Measure 5.1 & 44 & 43 & 43 & 40 & 3 \\
\hline Priority axis 5 & 44 & 43 & 43 & 40 & 3 \\
\hline Total & 4,439 & 1,918 & 1,906 & 1,546 & 360 \\
\hline
\end{tabular}

Source: Implementation agency of Slovak Ministry of Employment, Social Affairs and Family (2018) Annual reports of OP EaSI. 
The final drawdown after the implementation of the OP EaSI represents, for all projects without irregularities, the amount of funds of EUR 905348123.34 from the EU budget and EUR 157927421.69 from the state budget. The total drawdown of the OP EaSI in the amount of EUR 1063275545.05 represents the level of $96.18 \%$ of the total allocation for the programming period 2007-2013.

Table 3: Financial implementation of OP EaSI for the period 2007-2013

\begin{tabular}{|c|c|c|c|c|c|}
\hline OP EaSI & $\begin{array}{l}\text { Allocation of } \\
\text { the priority } \\
\text { axis/measure }\end{array}$ & $\begin{array}{l}\text { Total sum of } \\
\text { requested grants }\end{array}$ & $\begin{array}{c}\text { Total sum of } \\
\text { approved grants }\end{array}$ & $\begin{array}{c}\text { Total sum of } \\
\text { contracted } \\
\text { projects }\end{array}$ & $\begin{array}{c}\text { Total sum of } \\
\text { drawing for all } \\
\text { projects }\end{array}$ \\
\hline Measure 1.1 & $570,188,871$ & $976,070,511$ & $951,969,627$ & $857,520,387$ & $755,341,283$ \\
\hline Measure 1.2 & $200,266,659$ & $363,801,753$ & $149,905,627$ & $125,517,928$ & $57,482,388$ \\
\hline Priority axis 1 & $770,455,530$ & $1,339,872,263$ & $1,101,875,254$ & $983,038,315$ & $812,823,671$ \\
\hline Measure 2.1 & $84,083,530$ & $219,603,170$ & $159,332,830$ & $155,907,863$ & $102,715,610$ \\
\hline Measure 2.2 & $67,910,588$ & $146,354,070$ & $84,164,710$ & $78,288,742$ & $20,133,966$ \\
\hline Measure 2.3 & $52,947,059$ & $80,718,821$ & $69,493,588$ & $43,829,704$ & $25,462,021$ \\
\hline Priority axis 2 & $204,941,177$ & $446,676,061$ & $312,991,128$ & $278,026,309$ & $148,311,597$ \\
\hline Measure 3.1 & $8,052,656$ & $21,477,254$ & $12,662,400$ & $12,101,599$ & $9,756,066$ \\
\hline Measure 3.2 & $8,031,593$ & $11,788,123$ & $9,927,701$ & $9,539,893$ & $6,426,390$ \\
\hline Measure 3.3 & $4,021,063$ & $5,511,315$ & $5,311,451$ & $4,789,593$ & $2,181,853$ \\
\hline Measure 3.4 & 837,721 & 985,006 & 957,632 & 927,632 & 906,446 \\
\hline Priority axis 3 & $20,943,033$ & $39,761,698$ & $28,859,184$ & $27,358,717$ & $19,270,755$ \\
\hline Measure 4.1 & $66,842,518$ & $172,988,357$ & $92,316,343$ & $86,821,437$ & $39,278,253$ \\
\hline Measure 4.2 & 772,541 & $3,639,652$ & 489,636 & 489,636 & 337,910 \\
\hline Priority axis 4 & $67,615,059$ & $176,628,008$ & $92,805,979$ & $87,311,073$ & $39,616,163$ \\
\hline Measure 5.1 & $43,458,824$ & $55,608,451$ & $54,278,834$ & $54,273,057$ & $43,253,359$ \\
\hline Priority axis 5 & $43,458,824$ & $55,608,451$ & $54,278,834$ & $54,273,057$ & $43,253,359$ \\
\hline Total & $1,107,413,623$ & $2,058,546,481$ & $1,590,810,378$ & $1,430,007,472$ & $1,063,275,545$ \\
\hline
\end{tabular}

Source: Implementation agency of Slovak Ministry of Employment, Social Affairs and Family (2018) Annual reports of OP EaSI. 


\section{Selected social indicators rate in Slovakia in the context of the implementation of the OP EaSI in 2007-2013 period}

Generally, social indicators perform one or more of three functions: providing information for decision-making; monitoring and evaluating policies and/or searching for a common good and deciding how to reach it. In this paper, we have selected employment rate, unemployment rate and people at risk of poverty or social exclusion rate as key social indicators.

\section{Employment rate and unemployment rate}

We consider employment rate and unemployment rate as key social indicators to measure the impact of implementation of OP EaSI. The measures of active labor market policy contributed mostly to the increase of the employment rate and the decrease of the unemployment rate in Slovakia. Within the OP EaSI, the most significant part of the funds was allocated up to $70 \%$ in Priority Axis 1 - Support for Employment Growth, which, through its focusing activities and the nature of implemented projects, contributed mostly of all priority axes to the support of active labor market policy.

Graph 1: Employment rate in Slovakia from 2007 to 2017

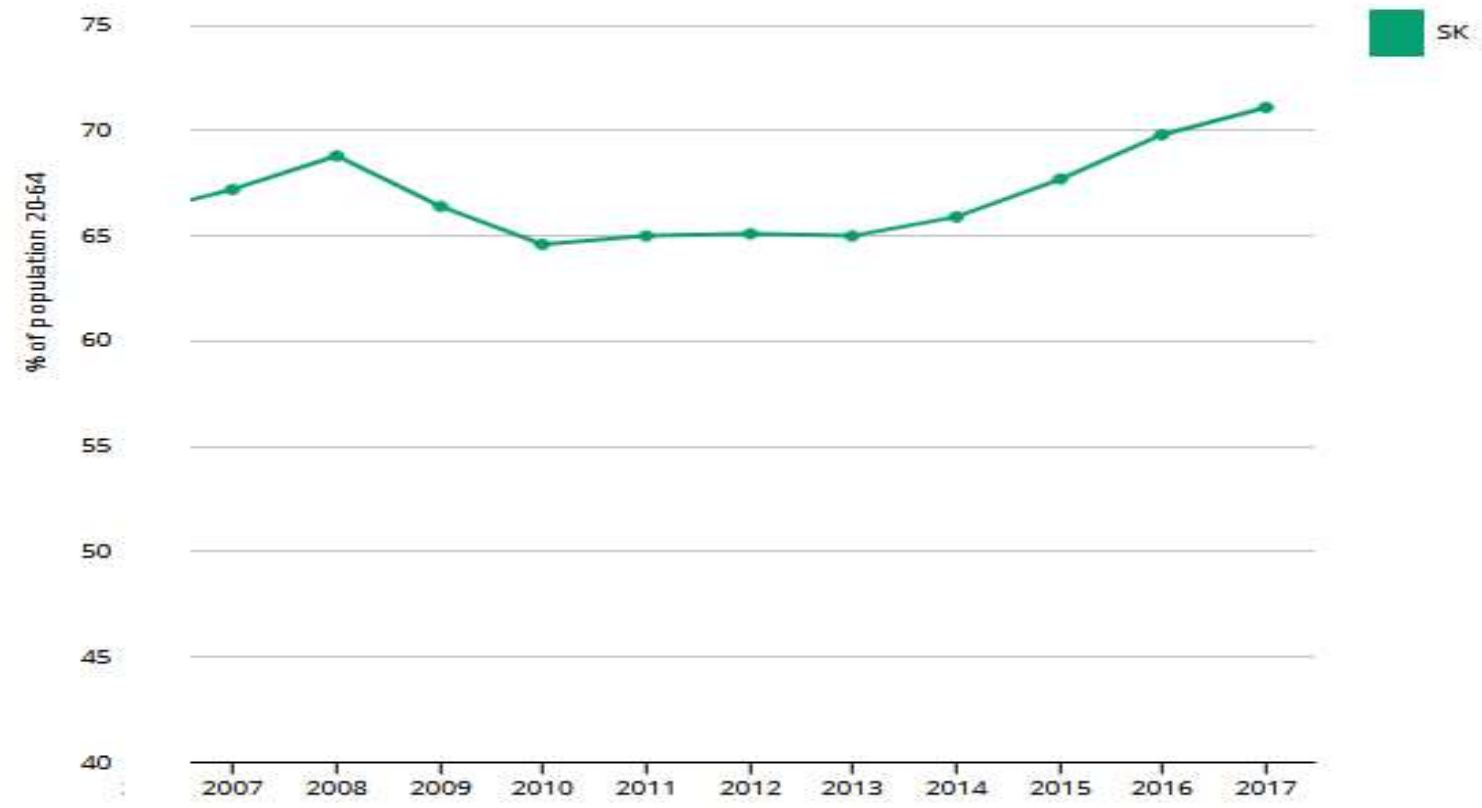

Source: Eurostat (2017) 
Graph 2: Unemployment rate in Slovakia from 2007 to 2017 in \%

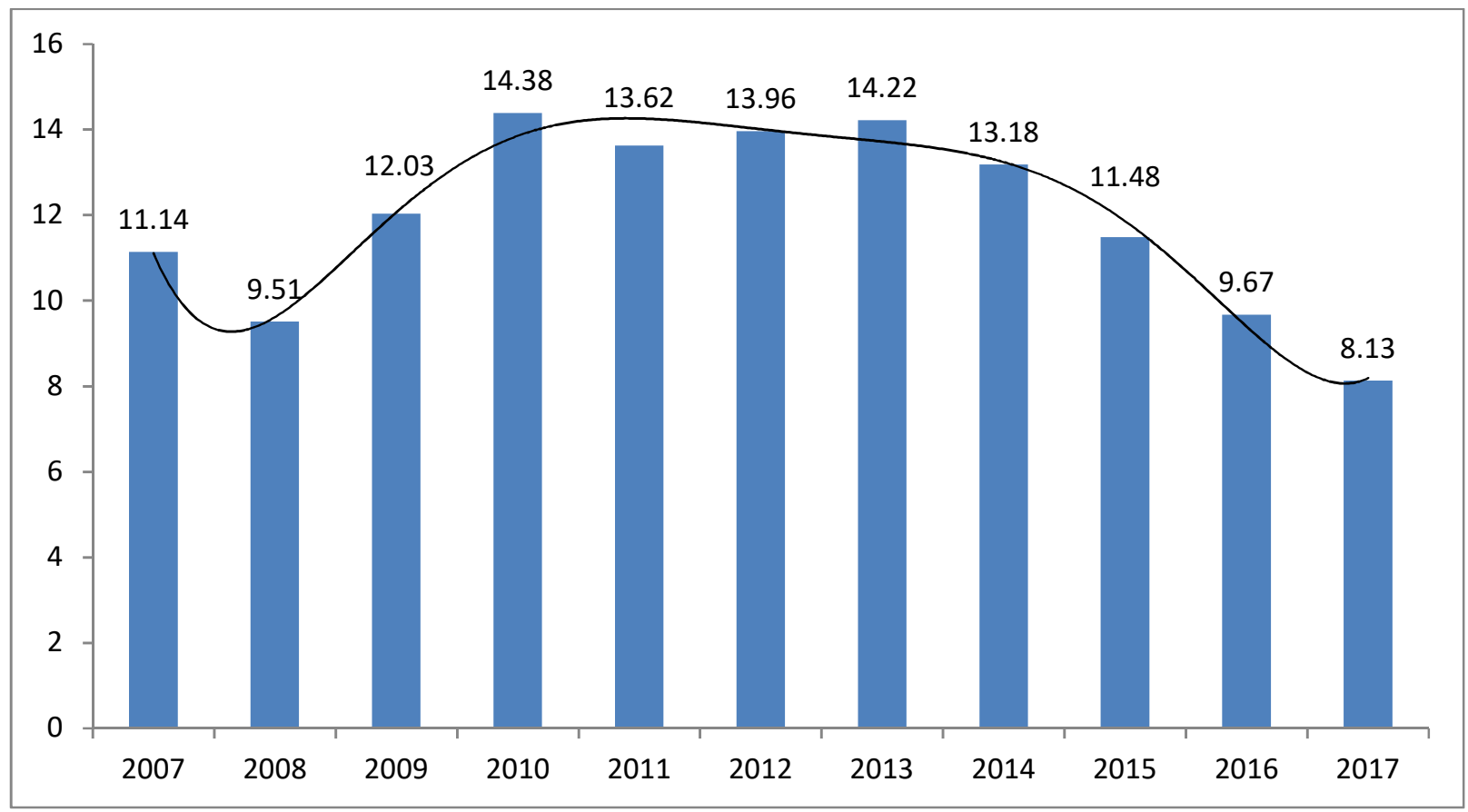

Source: own processing based on Statista (2017)

We have selected several indicators to demonstrate the success of these implemented measures. Indicator "The number of persons in the target group involved in the supported projects" managed to reach $254.65 \%$ when in total, 1509852 persons of the target groups were involved in the projects. Also the indicator "Number of successfully placed persons related to projects aimed at the placement of persons, people who are at risk of being dismissed from vacancies for job vacancies" reached above average level. This indicator was filled to almost $290.30 \%$, which represents 425243 people.

Table 4: Priority Axis 1: Fulfilment of physical indicators of contracted projects

\begin{tabular}{|l|l|l|l|l|l|l|l|l|l|l|l|}
\hline \multicolumn{2}{|l|}{ Indicators } & & 2007 & 2008 & 2009 & 2010 & 2011 & 2012 & 2013 & 2014 & 2015 \\
\hline \begin{tabular}{l} 
The $\begin{array}{l}\text { Achieved } \\
\text { number of } \\
\text { people in } \\
\text { the target }\end{array}$ \\
\cline { 2 - 13 }
\end{tabular} & 0 & 5,119 & 210,476 & 254,302 & 881,045 & $1,210,605$ & $1,303,997$ & $1,355,584$ & $1,509,852$ & $1,509,852$ \\
\hline
\end{tabular}




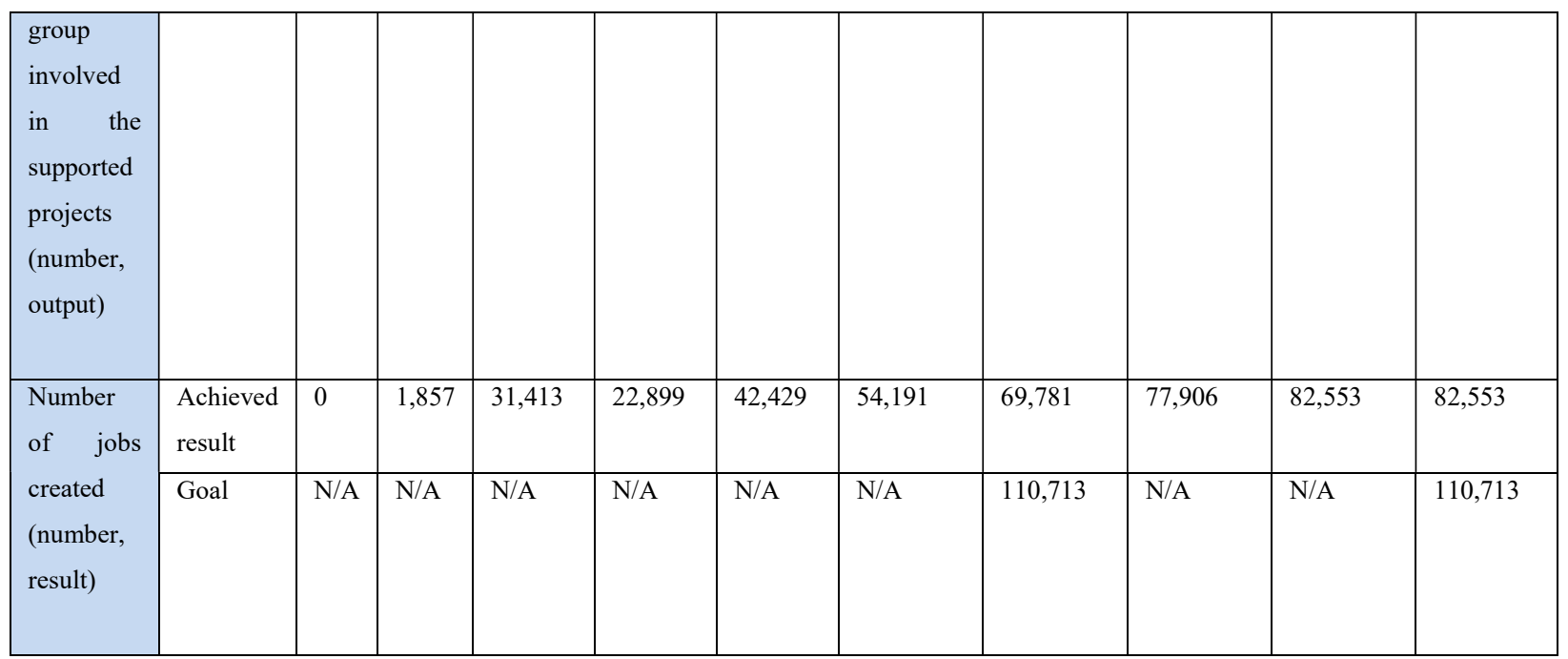

Source: Implementation agency of Slovak Ministry of Employment, Social Affairs and Family (2018) Annual reports of OP EaSI.

During the implementation of the OP EaSI, more than 82,000 new jobs have been created; most of them are sustainable, meaning that those who have been supported have retained their job for more than one year. With these contributions, more than 108,000 vacant or unoccupied jobs were filled. From the point of view of meeting the OP EaSI global target, the projected values of the indicators were set in the pre-crisis years, meaning that the measures were directed to areas with sufficient absorption capacity.

The implementation process has been heavily influenced by the crisis developments in the global economy and the need to prefer, in particular, the active labor market measures to promote employment. These measures taken as a reaction to the crisis can be considered successful, since the rate of employment has increased every year since 2010 after the temporary depression in 2008 and 2009.

Especially projects of the OP EaSI that support the employment of young people under the age of 29 can be considered very successful. By implementing these projects, nearly 13,000 new jobs were created for young people in different areas. Based on these contributions, the most significant achievements have been reached in the categories of helping employing young people under the age of 25 in the SR since 2012. According to European statistics, by 2016, unemployment in this category fell from $34.9 \%$ to $23.7 \%$, a decrease of $11.2 \%$ point. It has also created mostly sustainable jobs, with $86 \%$ of young people still remaining in permanent 
employment at the end of the project for those employers who received funding from the operational program.

Five of the projects aimed at supporting the employment of young people under the age of 29 have invested a total of nearly EUR 70 million, which helped young unemployed in different ways by creating a new job, gaining experience or retraining them. In the fields of support of the so-called more public employment, more than 7,200 unemployed have been employed. By financing retraining courses, more than 15,000 people were supported.

To achieve the main objective of the OP EaSI - Increasing employment and adaptability and reduction of unemployment, active labor market measures have contributed to in a major way by implemented national projects. In the 2007-13 programming period, active labor market policy measures and reform reforms were adopted to increase employment, mitigate regional disparities, reduce long-term unemployment, youth unemployment, and support the creation of new jobs.

Better account was taken of the situation in regional labor markets, increased targeting to a target group of particularly disadvantaged job seekers, long-term unemployed citizens, young people, people over 50 years of age and job seekers with low or no education.

\section{People at risk of poverty or social exclusion rate}

In line with the goals of the Europe 2020 Strategy (Dul'ová Spišáková et al., 2017), the SR has defined a specific objective in the area of poverty eradication, namely: "To extract at least 170,000 people from the risk of poverty and exclusion by 2020 ". The SR seeks to reduce the risk of poverty and social exclusion by strengthening and by promoting social inclusion measures. It is primarily about streamlining the current and introducing new measures to assist people in material need, as well as other measures aimed at adequate income, improving the quality of social services, measures for the social and legal protection of children, support for families, especially when reconciling their family and working lives etc.

Implementation of OP EaSI contributed significantly to the fulfillment of objective no. 5 of the Europe 2020 Strategy - Combating poverty and social exclusion, enabling socially excluded people to participate actively in the life of society as well as supporting the fight against discrimination and addressing the particular circumstances of particularly vulnerable groups, in particular by meeting the objectives of the implemented National projects. 
Table 5 People at risk of poverty or social exclusion rate in SR 2007-2017 in \%

\begin{tabular}{|l|l|l|l|l|l|l|l|l|l|l|l|}
\hline & $\mathbf{0 0 7}$ & $\mathbf{0 0 8}$ & $\mathbf{0 0 9}$ & $\mathbf{0 1 0}$ & $\mathbf{0 1 1}$ & $\mathbf{0 1 2}$ & $\mathbf{0 1 3}$ & $\mathbf{0 1 4}$ & $\mathbf{0 1 5}$ & $\mathbf{0 1 6}$ & $\mathbf{0 1 7}$ \\
\hline Slovakia & 1,4 & 0,6 & 9,6 & 0,6 & 0,6 & 0,5 & 9,8 & 8,4 & 8,4 & 8,1 & 6,3 \\
\hline
\end{tabular}

Source: Eurostat (2017)

\section{Conclusion}

The OP EaSI was implemented in the programming period 2007-2013 by the Ministry of Labor, Social Affairs and Family of the SR. The aim of the operational program was to increase employment, social inclusion and capacity building. Due to the low flexibility and efficiency of the staff in various areas of public administration, as well as the need to improve policy-making, the OP EaSI supported activities aimed at improving human capital and activities oriented towards quality policy making. OP EaSI was financed from the ESF and was implemented through five priority axes.

The implementation of the OP EaSI can be considered successful on the basis of results of realized projects and objectives achieved. The OP EaSI helped mitigate the impact of the crisis on employment, started community-wide social and community work, several other innovative national projects in the field of social inclusion helped in particular by supporting capacity building education. The OP EaSI belonged undoubtedly among the most successful programs in 2007-2013 in terms of the achieved level of drawing, but also in the scope of concrete socio-economic results achieved. The funds allocated for this program were used at the level of $96.18 \%$. The overwhelming majority of indicators have been fulfilled at the requested level. The total number of regularly completed projects was 1,546 out of 1,906 overall contracted projects for the period 2007-2013.

The main objective of this paper was to analyze the impact of implementation of OP EaSI on the selected social indicators such as employment rate, unemployment rate and people at risk of poverty or social exclusion rate in Slovakia during 10 years period 2007-2017. When we consider the course of development of the unemployment rate in Slovakia in the 10 year period from 2007 to 2017 in the context of above mentioned indicators, we came to a conclusion that 
there was a significant impact of the Implementation of the OP EaSI. The unemployment rate in Slovakia in 2007 was $11.14 \%$. With the contribution of OP EaSI, Slovakia was able to reduce unemployment in the long term. With the unemployment rate at $8.13 \%$ in 2017 , Slovakia reached the historical minimum.

Regarding the employment rate, it was heavily influenced by the crisis in 2008 and 2009, but thanks to measures taken, especially active labor market measures supported mostly by Priority Axes 1, the rate increased every year since 2010. The employment rate in Slovakia in 2007 was 63.6\%. During the implementation of the OP EaSI, more than 82,000 new jobs were created; most of them are sustainable, meaning that those who had been supported had retained their job for more than one year. With these contributions, more than 108,000 vacant or unoccupied jobs were filled. In 2017, the employment rate in the SR was $71.1 \%$, which was also the historical record.

In the field of combating poverty and social exclusion, the OP EaSI had a strong contribution to the people at risk of poverty or social exclusion rate in the SR 2007-2017, which decreased every year during that period, except 2009 as a consequence of the crisis. In 2007, it was $21.4 \%$ and in 2017 it was at the historical minimum of $16.3 \%$.

Every year, the ESF is helping approximately one million European citizens to get new jobs, education or qualifications. A successful implementation of OP EaSI was a good starting point for the preparation of the implementation of the current 2014-2020 programming period in which the SR, through the implementation of projects of the OP Human Resources according to EU recommendations, focuses mainly on long-term unemployment, youth unemployment, support for inclusive education and integration of marginalized groups.

\section{References}

1. ANDRONICEANU, A., GHERGHINA, R., CIOBĂNAȘU, M. (2019). The interdependence between fiscal public policies and tax evasion. Administratie si Management Public, (32), pp. 32-41, DOI: 10.24818/amp/2019.32-03

2. BALCERZAK, AP. 2016. Fiscal burden in the European union member states. Economic Annals-XXI, 161 (9-10), pp. 4-6

3. BONOLI, G. (2010) The political economy of active labour market policy. Politics \& Society 38: 435-457 
4. BÖHNKE, P. (2004). Perception of social integration and exclusion in an enlarged Europe, Office for Official Publications of European Communities, Luxemberg, 2004. 62 p. ISBN 92-897-0246-X

5. BRZESZCZAK, A. and IMIOŁCZYK, J. (2016). Ratio analysis of Poland's sustainable development compared to the countries of the European Union. Acta Oeconomica Universitatis Selye 5 (2), $31-41$

6. CALMFORS, L. (1994). Active labour market policy and unemployment - a framework for the analysis of crucial design features. OECD Economic studies No.22, Spring 1994.

7. CENTRAL COORDINATION BODY (2007). Národný strategický referenčný rámec 2007 - 2013. [online] Available at: http://www.nsrr.sk/en/narodny-strategicky-referencny-ramec2007-2013/

8. DUL'OVÁ SPIŠÁKOVÁ, E., MURA, L., GONTKOVIČOVÁ, B., HAJDUOVÁ, Z. (2017). R\&D in the context of Europe 2020 in selected countries. Economic Computation and Economic Cybernetics Studies and Research, 51 (4), pp. 243 - 261.

9. EUROPE 2020 STRATEGY (2018). [online] Available at: https://ec.europa.eu/info/business-economy-euro/economic-and-fiscal-policy-coordination/eueconomic-governance-monitoring-prevention-correction/european-semester/framework/europe2020-strategy_en

10. EUROSTAT (2017). Employment rate in Slovakia in 2007-2017. [online], Available at: https://ec.europa.eu/eurostat/statistics-explained/index.php/Employment_statistics

11. EUROPEAN UNION (2015). Council Decision (EU) 2015/1848 on guidelines for the employment policies of the Member States for 2015. [online], Available at: https://eurlex.europa.eu/legal-content/EN/TXT/?uri=OJ\%3AJOL_2015_268_R_0005

12. EUROPEAN UNION (2018). Financial framework 2007 - 2013. [online] Available at: http://ec.europa.eu/budget/figures/fin_fwk0713/fwk0713_en.cfm\#cf07_13

13. GERBERY, D., DŽAMBAZOVIČ, R. (2011). Inovatívne orientácie v sociálnej politike: Perspektíva sociálnej inklúzie. Bratislava: Univerzita Komenského v Bratislave, 2011. 132 p. ISBN 978-80-223-2998-9

14. GREVE, B. (2018). Social and Labour Market Policy: The Basics. Abingdon: Routledge, 2018. 139 p. ISBN 97-811-3855-7291. 
15. HETTEŠ, M. (2013). Zamestnanost' a sociálna práca. Bratislava: Vysoká škola zdravotníctva a sociálnej práce sv. Alžbety. 2013. 130 s. ISBN 978-80-8132-089-7.

16. HORECKÝ, J. (2018). Operation and action of a trade union (in terms of Czech Republic labour law). Central European Journal of Labour Law and Personnel Management, 1 (1), 17 - 27 . http://doi.org/10.33382/cejllpm.2018.01.02

17. HOTZ, V. JOSEPH, GUIDO IMBENS, AND JACOB KLERMAN. (2006). Evaluating the Differential Effects of Alternative Welfare-to-Work Training omponents: A Reanalysis of the California GAIN Program. Journal of Labor Economics 24: 521-566

18. CHOCHOLATÁ, M., FURKOVÁ, A. (2018). The analysis of employment rates in the context of spatial connectivity of the EU regions. Equilibrium. Quarterly Journal of Economics and Economic Policy, 13(2), 181-213. https://doi.org/10.24136/eq.2018.010

19. IMPLEMENTATION AGENCY OF SLOVAK MINISTRY OF EMPLOYMENT, SOCIAL AFFAIRS AND FAMILY (2018) Annual reports of OP EaSI. [online] Available at: https://www.ia.gov.sk/sk/dopytovo-orientovane-projekty/programove-obdobie-200720133/dokumenty/vyrocne-spravy-stav-cerpania-suhrnne-ziadosti-o-platbu

20. KARGOL-WASILUK, A., \& WILDOWICZ-GIEGIEL, A. (2018). The quality of public finance in the light of fiscal governance concept: implications for the European Union countries. Equilibrium. Quarterly Journal of Economics and Economic Policy, 13(3), 411-426. https://doi.org/10.24136/eq.2018.020

21. KOVÁČOVÁ, E. et al. (1995). Teória a politika zamestnanosti. Bratislava: Ekonóm, 1995. 269 p. ISBN 80-225-0700-8.

22. KUBÍK, J., ZU゚VALA, R. (2018). Division of labor in transport and the influence of the public sector. Administratie si Management Public, (30), 6-23. DOI: 10.24818/amp/2018.30-01

23. LAYARD, R., S. NICKELL AND R. JACKMAN. (1991) Unemployment: macroeconomic performance and the labour market. Oxford University Press

24. LEWANDOWSKA-GWARDA, K. (2018). Female unemployment and its determinants in Poland in 2016 from the spatial perspective. Oeconomia Copernicana, 9(2), 183-204. https://doi.org/10.24136/oc.2018.010

25. LIETAVA, M., FÁZIKOVÁ, M. 2017. Selection of EU finaced projects and the territorial cohesion. Acta Oeconomica Universitatis Selye 6 (1), 71 - 82 
26. MANOVÁ, E., ČULKOVÁ, K., SIMONIDESOVÁ, J., LUKÁČ, J. 2018. Evaluation of macroeconomic position of chosen EU countries. Acta Oeconomica Universitatis Selye 7 (2), 80 $-90$

27. MAREŠ P. and SIROVÁTKA T., 2008. Sociální vyloučení (exkluze) a sociální začleňování (inkluze) - koncepty, diskurz, agenda. Czech Sociological Review, 44, (2) 2, 271294.

28. MÉSZÁROS, M. (2018). Employing of self-employed persons. Central European Journal of Labour Law and Personnel Management, 1 (1), 46 - 67. http://doi.org/ 10.33382/cejllpm.2018.01.04

29. MINISTRY OF FINANCE OF THE SLOVAK REPUBLIC. (2014). National reform program 2014, [online], Available at: https://www.finance.gov.sk/Default.aspx?CatID=5197

30. MINISTRY OF FINANCE OF THE SLOVAK REPUBLIC (2018). Programové obdobie 2007 - 2013. [online] Available at: http:/www.finance.gov.sk/Default.aspx?CatID=6231

31. MINISTRY OF FINANCE OF THE SLOVAK REPUBLIC (2018). Programové obdobie 2007 - 2013. [online] Available at: http://www.finance.gov.sk/Default.aspx?CatID=6231

32. MINISTRY OF LABOR, SOCIAL AFFAIRS AND FAMILY OF THE SLOVAK REPUBLIC. (2013). The Operational Program Employment and Social Inclusion. [online], Available at: http://www.esf.gov.sk/documents/OP2007/OpZaSI_Final2007.pdf

33. MINISTRY OF LABOR, SOCIAL AFFAIRS AND FAMILY OF THE SLOVAK REPUBLIC. (2013). Employment support. [online], Available at: http://www.employment.gov.sk/sk/praca-zamestnanost/podpora-zamestnanosti/

34. MINISTRY OF LABOR, SOCIAL AFFAIRS AND FAMILY OF THE SLOVAK REPUBLIC. (2013). The Operational Program Employment and Social Inclusion. [online], Available at: http://www.esf.gov.sk/documents/OP2007/OpZaSI_Final2007.pdf

35. MINISTRY OF LABOR, SOCIAL AFFAIRS AND FAMILY OF THE SLOVAK REPUBLIC. (2013). Employment support. [online], Available at: http://www.employment.gov.sk/sk/praca-zamestnanost/podpora-zamestnanosti/

36. MINISTRY OF LABOR, SOCIAL AFFAIRS AND FAMILY OF THE SLOVAK REPUBLIC. (2014) National employment strategy of the Slovak Republic until 2020. [online], Available at: https:/www.employment.gov.sk/files/slovensky/praca-zamestnanost/podporazamestnanosti/national-employment-strategy-slovak-republic-until-2020.pdf 
37. MURA, L., GONTKOVICOVA, B., DULOVA SPISAKOVA, E., HAJDUOVA, Z. 2019. Position of Employee Benefits in Remuneration Structure. Transformations in Business \& Economics, 18, 2 (47), 156-173

38. MURA, L., VLACSEKOVÁ, D. 2018. Motivation of public employees: case study of Slovak teaching and professional staff. Administratie si Management Public, (31), 67-80. DOI: 10.24818/amp/2018.31-05

39. NAGY, B. Z. (2016). Regional inequalities in the European Union. Acta Oeconomica Universitatis Selye 5 (1), 109 - 118

40. OECD. "Measuring Social Well-Being: A Progress Report on the Development of Social Indicators". 1976. Paris: OECD

41. PÁLENÍK, M. et al. (2014): Politika zamestnanosti budúcnost' pre Slovensko. Bratislava: Institute of employment. 267 p. ISBN 978-80-970204-6-0.

42. STATISTA (2017). Unemployment rate in Slovakia in 2007-2017. [online], Available at: https:/www.statista.com/statistics/375276/unemployment-rate-in-slovakia/

43. UNITED NATIONS (2013). Sustainable Development Challenges. New York: United Nations publication. Sales No. E.13.II.C.1. ISBN 978-92-1-109167-0.

44. WORKIE TIRUNEH, M. (2013): Does Labour Force Education Accelerate the Speed of Convergence? Empirical Evidence from Selected EU Countries. Journal of Economics 04, 344 357 ,

45. WORKIE TIRUNEH, M. and ŠTEFÁNIK, M., et al. (2014). Trh práce na Slovensku: Analýzy a prognózy. Bratislava: EÚ SAV. 228 p. ISBN 978-80-7144-233-2. 